\title{
KEBERGANTUNGAN PENGKOTBAH TERHADAP PERAN ROH KUDUS DALAM PERSIAPAN DAN PENYAMPAIAN FIRMAN TUHAN
}

\author{
Suriawan \\ Sekolah Tinggi Theologia Abdiel \\ pdt.suriawan@gmail.com
}

\begin{abstract}
The sermon is one of the central activities of the church liturgy. The role of the sermon is very important in the Christian ministry, but now we have found several problems of the sermon at the church pulpit. Nowadays, the preacher can easily get the material resources either from books or electronic journal and so on to prepare the sermon. But unfortunatelly, there are many sermons that cannot be applied in daily life or in the other word, such sermons have the poor application. This article wants to emphazise the role of the Holy Spirit for the preacher in preparing the sermon. Why do we need to depend on the role of the Holy Spirit in preparing the sermon? What do mean that we need to depend on the power of the Holy Spirit? These questions above will be discussed in this paper.
\end{abstract}

Keywords: Holly Spirit, preacher, sermon, word of God

\section{Pendahuluan}

Menurut Benny Solihin dalam pendahuluan bukunya "7 Langkah Menyusun Kotbah yang Mengubah Kehudupan” ada lima persoalan pada kotbah-kotbah masa kini: Pertama, persoalan tentang kebergantungan pada Roh Kudus. Kedua, persoalan tentang isi kotbah. Ketiga, persoalan tentang aplikasi kotbah, dan keempat tentang cara penyajian kotbah dan kelima, tentang diri pengkotbah. ${ }^{1}$ Dari kelima persoalan tersebut tentunya semuanya harus dicarikan pemecahannya namun demikian tulisan ini hanya akan membatasi diri untuk hanya mendalami persoalan pertama saja dan berusaha menjawabnya, yakni tentang masalah kurangnya kebergantungan pada Roh Kudus secara khusus lagi dalam persiapan dan penyampaian kotbah pada pengkotbah masa kini.

Lebih lanjut Benny menyoroti tentang persoalan pertama ini dengan penuh keprihatinannya, dimana ketika sarana penolong dalam membuat persiapan kotbah bisa semakin mudah diperoleh. Yakni bisa melaui buku-buku tafsir dan banyaknya PDF yang bisa diunduh dengan gratis, belum lagi software-software Alkitab, ribuan website yang

${ }^{1}$ Benny Solihin, 7 Langkah menyusun Kotbah yang Mengubah Kehidupan (Malang: Literatur SAAT, 2014), 8-10. 
menyediakan baik bahan mentah dan kotbah lengkap yang sudah jadi bahkan disertai ilustrasi. Belum lagi dengan banyaknya buku-buku Sosiologi, Psikologi dan Filosofi, serta berita-berita up date dari media cetak dan elektronik yang dapat dengan mudah menganalisis dunia pendengar.

Belum lagi kecanggihan teknologi multimedia seperti powerpoint yang membantu pengkotbah dalam menyajikan kotbahnya dengan lebih menarik. Dimana sebenarnya semua sarana itu telah menjadi berkat yang luar biasa bagi para pengkotbah, dimana semua fasilitas itu tidak ada di waktu yang lalu. Namun disinilah ironisnya, ditengah-tengah kemudahan tersebut, tidak jarang kita mendengar keluhan dari jemaat bahwa kotbahkotbah yang para pengkotbah sampaikan tidak menarik, tidak relevan, dan yang menjadi persoalan ini semakin serius adalah tidak adanya kuasa atau power, yang dalam bahasa gereja-gereja Pentakosta-Kharismatik disebut urapan dari Roh Kudus. ${ }^{2}$ Persoalan ini ternyata telah menjadi masalah mimbar yang mendunia di satu abad terakhir ini, seperti diprihatinkan dan diungkapkan olehJerry Vines dan Jim Shaddix dalam buku "Power in the Pulpit":

Seorang pegkotbah mungkin berusaha membuat para pendengarnya terkesan dengan logika dan ketrampilannya; tetapi cara itu sebenarnya malah membuat mereka tidak tergugah pada tingkat terdalam eksistensi mereka. Paulus menjelaskan bahwa penyampaian kotbah yang efektif tidak bergantung pada ketrampilan si pengkotbah. Sementara kita bisa dan harus memohon pelbagai kuasa pada Allah, penyampaian kotbah yang benar-benar efektif hanya terjadi bilamana kekuatan Roh Kudus terlibat. ${ }^{3}$

Apakah yang kiranya menyebabkan persoalan utama ini bisa terjadi? Tentu ada banyak faktor yang bisa dicari menjadi penyebabnya, tetapi kemungkinan terbesarnya adalah karena kegagalan pengkotbah dalam memahami peranan Roh Kudus baik dalam kehidupan pengkotbah secara pribadi, terkhusus dalam persiapan kotbah dan dalam penyampaian kotbahnya. Benny Solihin menegaskan,

Pengkotbah tidak lagi mempunyai sense of the supernatural dalam berkotbah sehingga kotbah dirasakan hanya merupakan suatu aktifitas manusia belaka, bukan aktivitas Allah. Pada masa kini, mungkin saja berkotbah telah dianggap sebagai suatu profesi, tugas rutin, pameran kemampuan akademis, atau dipandang sebagai suatu acara "entertaiment". 4

\footnotetext{
${ }^{2}$ Ibid., 6-7.

${ }^{3}$ Jerry Vines dan Jim Shaddix, Homiletika: Kuasa dalam Berkotbah-Persiapan dan Penyampaian Kotbah (Malang: Gandum Mas, 2002), 20.

${ }^{4}$ Beny solihin, 7 Langkah, 6.
} 
Hal senada juga disampaikan oleh Arturo G Azurdian III dalam bukunya Spirit Empowered Preaching, "Saya sangat yakin bahwa kekurangan terbesar dalam pelayanan kotbah ekspositori zaman sekarang adalah tidak adanya kuasa; dengan kata lain kotbah tidak mengandung daya hidup dari Roh Kudus". ${ }^{5}$ Ia kemudian mengutip peryataan seorang pendeta Presbiterian yang berkata:

Keinginan terbesar pada zaman sekarang adalah pelayanan yang lebih kudus. Kita tidak membutuhkan lebih banyak polemik pendukung apologet yang hebat, atau pengkotbahyang berpengetahuan luas, walaupun semua itini penting. Tetapi kita membutuhkan utusan Allah yang membawa suasana surga ke mimbar dan berbicara dari perbatasan dunia lain. ${ }^{6}$

Azurdian III bahkan secara mendalam mengangkapkan bahwa kotbah-kotbah yang membuat pendengar merasakan kuasa Allah dan yang mendorong pendengar mengasihi Allah adalah kotbah-kotbah yang berasal dari penguraian firman Tuhan yang teliti dan cermat, namun lebih dari pada itu adalah kotbah-kotbah yang dialiri oleh kuasa yang tak terbatas yang melampaui kekuatan manusia yaitu kuasa Roh Kudus. ${ }^{7}$ Semua itu akan terjadi apabila ada pengkotbah-pengkotbah yang mempunyai kebergantungan yang penuh pada pimpinan Roh Kudus.

\section{Mengapa Pengkotbah harus Bergantung pada Roh Kudus?}

Masalah ketidakbergantungan terhadap Roh kudus sebenarnya tidak saja menjadi kian masif di zaman modern dengan semakin banyaknya kemudahkan untuk dapat semakin mengerti Firman Tuhan dengan begitu limpahnya bahan untuk studi. Masalah ini juga telah menjadi persoalan sejak zaman Perjanjian Baru ditulis:

Kebergantungan pada Roh Kudus dan kebijaksanaan dari atas mungkin tidak begitu populer di kalangan pengajar dan filsuff zaman Perjanjian Baru. Paulus memperingatkan Timotius akan perlawanan (keberatan, pertentangan, antitesis) yang "berasal dari apa yang disebut pengetahuan" (I Timotius 6:20). Beberapa keberatan itu mungkin berkaitan dengan penolakan oknum dan hubungan pribadi Roh Kudus. Setidak-tidaknya, tidak lama kemudian guru-guru palsu memaklumkan bahwa Roh Kudus hanyalah penyataan "kekuatan Allah". Akan tetap, semua keberatan dan antitesis guru-guru itu hanya menyebabkan kebingungan. Ketergantungan pada Kristus dan Roh Kudus adalah satusatunya jalan menuju kedamaian. ${ }^{8}$

\footnotetext{
${ }^{5}$ Aruro G. Azurdian III, Spirit Empowered Preaching (Yogyakarta: Andi, 2009), xx.

${ }^{6}$ Ibid., xxiv.

${ }^{7}$ Ibid., Xx.

${ }^{8}$ Stanley M. Horton, Oknum Roh Kudus (Malang: Gandum Mas, T.th), 10.
} 
Mengingat masalah ini telah terjadi sekian lamanya dan begitu krusial maka sangat diperlukan suatu kajian yang kiranya akan semakin menggugah kesadaran kita bersama sebagai orang-orang yang dipanggil sebagai pemberita Firman Tuhan untuk semakin serius dalam menanggapi dan mempopulerkan hal bergantung pada Roh Kudus.Sehingga apa yang diharapkan dalam kutipan dibawah ini terjadi.

Penyampaian kotbah yang diurapi Roh Kudus memberikan sesuatu kepada pengkotbah dan pendengarnya. Urapan tersebut menyadarkan pengkotbah dan pendengarnya. Urapan tersebut akan menyadarkan pengkotbah akan adanya kekuatan lain yang tidak dimilikinya. Tepatnya, ia "dikuasai" - terperangkap dalam pesan tersebut oleh kuasa Roh Kudus. Ia menjadi wahana yang digunakan Roh Kudus. Pada waktu bersamaan, orang-orang yang hadir terpikat, tergugah dan diyakinkan. Bilamana Roh Kudus mengambil alih penyampaian kotbah, sesuatu yang luar biasa terjadi. ${ }^{9}$

Berikut adalah alasan empat alasan mendasar mengapa pengkotbah harus bergantung pada Roh Kudus ${ }^{10}$ :

1. Kotbah bukanlah penemuan manusia, tetapi kreasi Tuhan

Berkotbah adalah pekerjaan Tuhan atau kreasi Tuhan, hal ini bisa dilihat dari tujuan kotbah itu sendiri yakni sebagai sarana untuk menyatakan kehendak-Nya kepada umat-Nya. Jadi ini bukanlah inisiatif dari manusia atau penemuan dari manusia. Seperti kita ketahui, Allah dalam Alkitab selalu berbicara dan ingin kehendak-Nya diketahui oleh umat-Nya. Pertama-tama Allah yang berbicara kepada nabi-nabi dan rasul-rasul dan baru dari sana mereka diminta Allah untuk menyampaikan Firman-Nya kepada umat-Nya. Seperti yang diucapkan oleh John Calvin:

Para nabi dan rasul tidak membanggakan kepandaian mereka ataupun sesuatu yang membuat orang percaya kepada ucapan mereka; mereka pun tidak menyodorkan alasan-alasan yang logis. Tetapi untuk membuat semua orang tunduk dan menurut, para nabi dan rasul itu menyebut nama Allah yang suci. ${ }^{11}$

Menyadari bahwa kotbah berasal dari Allah, berbicara tentang Allah dan Allah pula yang menjadi sumber kuasa dari firman-Nya, maka sudah sepatutnya pengkotbah memulai langkah pertamanya dengan bergantung kepada pimpinan Roh kudus-Nya.

\footnotetext{
${ }^{9}$ Ibid., 10

${ }^{10}$ Bdk. Benny Solihin, 33-35, Hanya mengupas tiga alasan dan penulis dalam tulisan ini mendalami ketiga alasan tersebut dan juga menambahkan satu alasan mendasar lagi di poin alasan yang keempat.

${ }^{11}$ John Calvin, Institutio (Jakarta, Gunung Mulia, 1993), 19.
} 
2. Hanya Kuasa Roh Kudus yang dapat mengubah manusia

Michael K. Shipman dalam bukunya yang berjudul Pembaharuan Pelayanan Mimbar, mengatakan suatu kalimat pertama dalam alinea bukunya bahwa: "Penyampaian firman Allah merupakan suatu pekerjaan rohani. Jadi, bila pengkotbah ingin berhasil dalam penyampaian kotbahnya, hal yang mendasar adalah ia harus mengenal Kristus dan dipenuhi Roh Kudus. Dengan demikian, ia dapat memberitakan Firman Allah dengan baik."12 Ketika seorang pengkotbah menyadari bahwa ketika dia dipercaya untuk menyampaikan Firman Tuhan, ia harus mengerti bahwa ini adalah pekerjaan rohani atau pekerjaan Allah, dimana ia tidak akan bisa melakukannya sendiri tanpa pengenalan pribadi kepada Yesus Kristus dan juga hidup yang bergantung sepenuhnya kepada Roh Kudus. Hal ini terkait secara khusus karena hanya lewat kuasa Roh Kuduslah yang dapat mengubah manusia.

Kotbah yang tidak disertai oleh Roh Kudus, mungkin saja dapat menarik tetapi tidak cukup untuk mengubah kehidupan. Paradigma ini seharusnya dipegang erat oleh pengkotbah. Kebanyakan pengkotbah sudah merasa cukup ketika sudah belajar ilmu Homelitika, yang menganggap kotbah hanya sebatas metode penyampaian, pengumpulan bahan-bahan dan ilustrasi yang dikemas dalam sebuah persiapan dan kemudian disampaikan. Kotbah memang melibatkan semua itu, tetapi kotbah tidak sekedar itu.

Kotbah adalah gabungan antara tindakan manusia dan Allah, namun kekuatan akhir yang mengubah hati dan pikiran manusia sesungguhnya adalah kuasa Roh Kudus sematamata, bukan kepandaian manusia bahkan sekalipun dia menguasai Homiletika sekalipun. Seperti apa yang pernah ditegaskan oleh Calvin, "Firman tidak akan dapat diterima di hati manusia sebelum dimetaraikan oleh Roh Kudus di dalam batin manusia." ${ }^{13}$ Dan untuk itu Calvin mempraktekkan, dimana setiap berjalan diatas mimbar dia selalu berdoa, Datanglah Roh Kudus, datanglah."14

Pemahaman ini lalu tidaklah dimaksud untuk mengabaikan usaha keras pengkotbah, melainkan untuk menyadarkan pengkotbah bahwa kalau tanpa Roh Kudus bekerja, segala usaha keras dan talentanya akan menjadi sia-sia.

3. Alkitab sebagai dasar kotbah diinspirasi dan diiluminasikan oleh Roh Kudus

Alkitab adalah dasar satu-satunya bagi para penyampai Firman Tuhan dalam menyampaikan pemberitaan Firman. Dan yang perlu di ketahui oleh para pengkotbah

\footnotetext{
${ }^{12}$ Michael K. Shipman, Pembaharuan Pelayanan Mimbar (Bandung: Yayasan Kalam Hidup, 2006), 5.

${ }^{13}$ Calvin, Institutio, 19.

14 Ibid., 23.
} 
adalah bahwa Alkitab itu diinspirasi oleh Roh Kudus, sehingga hanya mungkin dimengerti secara tepat (sebagaimana yang dimaksud penulisnya) dengan iluminasi atau penerangan dari Roh Kudus pula. Mengingat pentingnya hal ini, kita perlu membahas dengan lebih mendalam arti inpirasi dan iluminasi Roh Kudus.

\section{Inpirasi Roh Kudus}

Inspirasi/ pengilhaman (inspirations), istilah itu digunakan untuk memperlihatkan bahwa Alkitab sebagai penyataan diri Allah ditulis oleh penulisnya dengan pimpinan Roh Kudus. Paulus menuliskan hal ini dalam 2 Timotius 3:16, "Segala tulisan yang diilhamkan Allah memang bermanfaat untuk mengajar, untuk menyatakan kesalahan, untuk memperbaiki kelakuan dan untuk mendidik orang dalam kebenaran. Kata-kata "segala tulisan yang diilhamkan Allah", hal ini tentu dapat kita sebut tentang Firman Allah yang ditulis oleh para penulis Alkitab. Hal ini seperti apa yang dikatakan oleh Daniel Lukas Lukito yang menjelaskan:

Theopneustos (god-breathed, dihembuskan Allah) adalah kata majemuk yang merupakan sebuah pengakuan eksplisit bahwa Allah adalah pengarang tunggal di belakang penulis Alkitab ... 2 Timotius 3:16 (dan juga Rm. 3:2) meneguhkan bahwa Allah yang hidup itu adalah Pengarang tunggal Alkitab dan Alkitab adalah produk dari nafas atau hembusan Allah yang kreatif atau yang bersifat mencipta. 15

Pengertian ini yaitu bahwa Alkitab diinspirasi oleh Roh Kudus seharusnya membuat kita sebagai para penyampai Firman Tuhan selayaknya menaruh hormat pada saat membaca Alkitab. Sehingga waktu membaca tulisan-tulisan yang diinpirasikan Allah tidak sama nilainya dibandingkan ketika kita membaca tulisan-tulisan biasa seperti artikelartikel di koran, majalah, website bahkan buku-buku yang ada.

Andreas Sudjono dalam tulisannya berjudul "Inspirasi Roh Kudus bagi Pendeta dalam mempersiapkan Kotbahnya" memberikan tujuh point peranan Roh Kudus dalam memberikan inspirasi dalam kotbah: ${ }^{16}$

1) Roh Kudus memberi hikmat kepada pengkotbah untuk menentukan nats-nats atau ayat/ perikop yang akan dikotbahkan.

\footnotetext{
${ }^{15}$ Daniel Lukas, Pengantar Theologia Kristen I (Bandung: Kalam Hidup, 1992), 88, seperti dikutip oleh Benny Solihin, 36.

${ }^{16}$ Andreas Sudjono, Inspirasi Roh Kudus bagi Pendeta dalam mempersiapkan Kotbahnya, sumber dari: sttintheos.ac.id/e-journal/index.php/antusias/article/download/70/69 (diakses 28 Pebruari 2018).
} 
2) Roh Kudus memberikan pencerahan dan iluminasi kepada pengkotbah dan juga pendengar.

3) Roh Kudus menggerakkan ingatan pengkotbah pada nats lain, ilustrasi dan penerapan praktis yang masih berkaitan dengan nats kotbah yang disampaikan.

4) Roh Kudus memberikan keyakinan dan keberanian saat berkotbah.

5) Roh Kudus menginsafkan akan dosa, kebenaran dan penghakiman (Yoh.16:8).

6) Roh Kudus menanamkan Firman Tuhan dalam hati pengkotbah dan pendengar.

7) Roh Kudus juga memotivasi pendengar untuk melakukan Firman-Nya dalam kehidupannya.

Hal-hal yang hampir senada juga dikatakan oleh Billy Graham dalam bukunya "The Holy Sprit" yang membahas pekerjaan Roh Kudus di dunia saat ini yang menurutnya mempunyai dua segi. ${ }^{17}$ Pertama, Ia datang untuk menginsafkan dunia akan dosa, kebenaran dan penghakiman (Yohanes 16:7-11). Akan hal ini Billy Graham sendiri menyaksikan,

Pernah terjadi beberapa kali pada waktu saya sedang berkotbah, seseorang keluar dengan mengajungkan tinjunya kepada saya. Ia sesungguhnya bukan memusuhi saya. Saya tahu itu. Tetapi ia telah diyakinkan oleh Roh Kudus. Sering orang yang demikian itu kemudian berbalik dan menemukan Kristus. Roh Kudus saja meyakinkan manusia tentang dosa, Ia meyakinkan manusia bahwa bahwa Yesus adalah kebenaran dari Allah. Ia menunjukkan kepada orang berdosa bahwa Yesus adalah jalan, dan kebenaran, dan hidup, dan tak seorangpun sampai kepada Bapa kecuali dengan Dia (Yohanes 14:6). ${ }^{18}$

Kedua, menghalang-halangi pertumbuhan kedurhakaan (2 Tesalonika 2:7). Bahkan Billy Graham lebih lanjut berkata,"Alkitab sudah menyatakan dengan jelas bahwa planet ini sebenarnya akan menjadi neraka dunia kalau Roh Kudus tidak ada di dalam dunia ini. Orang-orang yang belum percaya hanya mengetahui sedikit akan hutangnya kepada kuasa Roh Kudus sebagai pelindung. ${ }^{19}$

\section{Iluminasi Roh Kudus}

Istilah Iluminasi atau penerangan dipahami sebagai tuntunan Roh Kudus kepada pembaca Alkitab dalam menafsir dengan tepat. Beny Solihin tentang hal ini menerangkan:

17 Billy Graham, Roh Kudus: Kuasa Allah dalam Hidup Anda (Bandung: Lembaga Literatur Babtis, 1985), 40-43.

${ }_{18}$ Ibid., 41 .

${ }^{19}$ Ibid., 42. 
Bahasa Yunani untuk iluminasi adalah Photizo (Inggris, anlighten) yang berarti "menerangi, menyinari." Kata ini berhubungan dengan tindakan Roh Kudus yang mengajar atau memberikan pengetahuan, bagaikan cahaya pengetahuan yang menembus dan menyibakkan gelapnya kebodohan. Perkataan Paulus dalam 2 Korintus 4:6 menunjukkan bagaimana iluminasi dihubungkan dengan pengetahuan, "Sebab Allah yang telah berfirman, 'Dari dalam gelap akan terbit terang!', Ia juga membuat terangnya bercahaya di dalam hati kita, supaya kita beroleh terang dari pengetahuan tentang kemuliaan Allah yang tampak pada wajah Kristus. ${ }^{20}$

Lebih lanjut Beny Solihin menjelaskan bahwa," Ini berarti, iluminasi Roh Kudus adalah bimbingan untuk memahami firman yang diinspirasikan-Nya. Roh Kudus bukan hanya pengarang sesungguh-sungguhnya, melainkan juga satu-satunya penafsir Alkitab yang sejati. Ia terlibat dalam proses penafsiran (hermeneutik) karena Ia adalah Roh Kebenaran."21 Hal ini sesuai dengan apa yang Tuhan Yesus pernah sampaikan dalam Yohanes 16:13, "Tetapi apabila Ia datang, yaitu Roh Kebenaran, Ia akan memimpin kamu ke dalam seluruh kebenaran ..." Roh Kudus sebagai Parakletos ("Penolong"; Yohanes 14:16, 26: 15:26) selalu mendampingi pengkotbah dalam menemukan arti yang sesungguhnya dari teks-teks Alkitab. John MacArthur, Jr. menyimpulkan hal ini dengan mengatakan bahwa, "Iluminasi adalah pekerjaan Roh Kudus yang membukakan mata rohani seseorang untuk mengerti arti firman Tuhan." ${ }^{22}$ Jadi sebenarnya Alkitab hanya dapat ditafsirkan dengan bantuan Roh kudus. Namun pertanyaannya adalah bagaimanakah Roh Kudus mengiluminasi pengkotbah dalam mendapatkan pengertian yang benar dari suatu teks Alkitab? Berikut adalah ha-hal yang perlu didalami dari pengertian Iluminasi Roh Kudus,

a. Ilumuniasi Roh Kudus tidak dimaksud mengambil alih tanggung jawab penyampai Firman untuk giat mendalami teks yang akan disampaikan.

Jika sebagai penyampai Firman kita berpikir bahwa karena Roh Kudus telah dan akan membimbing atau memberi pengertian, lalu yang diperlukan hanyalah berdoa dan membaca Alkitab saja. Sehingga kita tidak perlu membaca buku-buku tafsir dari manusia untuk menyelidiki latar belakang budaya dan sejarah dari suatu teks, tentulah hal-hal ini tidaklah tepat. Iluminasi Roh Kudus adalah pekerjaan Roh Kudus ketika penyampai Firman dengan rendah hati dan memiliki kerinduan mendalam untuk giat dalam

\footnotetext{
${ }^{20}$ Ibid.

21 Ibid., 37.

22 John MacArthur Jr., Rediscovering Expository preaching; Balancing the Science and Art of Biblical Expository. Peny. Richard L (Mayhue; Dalas: Word, 1992), 103.
} 
mempelajari atau mendalami suatu teks Alkitab yang hendak disampaikan. Iluminasi Roh Kudus telah nyata dirasakan adalah ketika telah menemukan 'amanat teks' dan berhasil menjadikan itu sebagai 'amanat kotbah' secara bertanggung jawab. Amanat teks itulah yang telah diinspirasikan Roh Kudus kepada penulis alkitab, maka menjadi tugas dan tanggung jawab kita untuk menemukan amanat teks tersebut. Dan untuk menemukan amanat teks tanpa kita belajar tentang latar belakang teks tidaklah mungkin. Dua hal terakhir inilah yang senantiasa penulis tekankan kepada para mahasiswa saat mengajar di kelas Homiletika.

Paulus menyatakan kepada Timotius bahwa Tuhan akan memberi kepadanya pengertian dalam segala sesuatu (2 Timoitus 2:7), tetapi ia juga mendorong anak rohaninya itu dengan berkata, "usahakanlah supaya engkau layak di hadapan Allah sebagai seorang pekerja yang tidak usah malu, yang berterus terang memberikan perkataan kebenaran itu" (2 Timotius 2:15). Dalam Alkitab terjemahan New American Standard ditulis, "Be diligent to present yourself approved to God as a workman who does not need to beashamed, handling accurately the word of truth." Kata "usahakanlah" mempunyai pengertian "rajinlah", dan frasa "yang berterus terang memberitakan kebenaran itu" dapat diartikan dengan yang menangani firman Tuhan secara akurat.

Jadi rasul Paulus mempunyai pandangan yang sama bahwa iluminasi Roh Kudus tidaklah meniadakan keraajianan seorang penyampai Firman dalam memahami Firman Tuhan. Buku-buku penolong seperti tafsiran, kamus-kamus Alkitab, interlinier, dan bukubuku lain dapat dikadikan sarana yang dipakai Roh Kudus untuk menerangi pikiran penyampai Firman dalam memahami suatu teks Alkitab dengan lebih baik. Kendati demikian penyampai Firman juga tetap berpikir kritis untuk tidak begitu saja menerima tafsiran-tafsiran yang ada. Disinilah peran Roh Kudus tetap kita minta untuk memberi hikmat untuk membedakan pandangan yang salah dan yang benar. Singkatnya, makin giat penyampai Firman menyelidiki Firman Tuhan, makin leluasa Roh Kudus bekerja membuka pikiran dan hati kita. "Seorang pengkotbah yang tidak mau tahu apa yang dikatakan oleh teks sesungguhnya sedang mengabaikan penulis teks itu sendiri, yakni Roh Kudus." 23 "Seorang pengkotbah yang tidak dapat mengklaim Roh Kudus mengurapi dia bila ia malas dalam persiapannya dan tidak melakukan penyelidikan teks dengan memadai. Roh Kudus tidak pernah menganggap bahwa studi seorang pengkotbah tidak penting,"24

\footnotetext{
${ }^{23}$ Beny Solihin, 7 Langkah, 39.
}

${ }^{24}$ Ibid., 40 . 
b. Iluminasi Roh Kudus dalam menafsir teks tidak mengabaikan penalaran penyampai Firman berpikir logis

Roh Kudus adalah Roh Kebenaran, ia tidak akan mengajarkan kepada kita konsepkonsep yang tidak memenuhi kreteria kebenaran. Untuk itu di dalam menafsir Alkitab, Tuhan menginginkan penyampai Firman untuk berpikir jernih, logis dengan menggunakan semua metode pemikiran yang umum, seperti induksi, deduksi, analogi, perbandingan, sebab-akibat, dan lain-lain. Karunia yang diberikan Allah kepada kita sebagai manusia yang melebihi mahkluk lain adalah kita diberi otak yang super untuk dapat berpikir secara baik sistematis dan logis.

Namun demikian kita tetap tidak boleh mendewakan pikiran kritis dan logis kita, semuanya itu tetap kita tundukkan pada pikiran Kristus, sikap takut dan hormat akan Firman menjadi penting dalam hal ini. Sebab dilain sisi kita tahu tentang keterbatasan dari pikiran kita dan bahkan yang sering kali mudah juga dibelokkan menjadi tidak objektif dan motifnya cenderung kepada kepentingan sendiri. Sebab itu kita sebagai para penyampai Firman perlu bergantung pada pimpinan Roh Kudus untuk membimbing pikiran dan hati kita dalam memahami kebenaran Firman Tuhan. Jadi penalaran dan berpikir logis disini adalah untuk digunakan secara kontruktif dalam menafsir Alkitab demi membangun iman jemaat.

c. Iluminasi Roh Kudus dalam menafsir Alkitab tidak berarti bahwa hanya mereka yang belajar Hermeunika saja yang dapat menafsir Alkitab

Kotbah para lulusan sarjana Teologia bahkan Master juga Doktor Teologi bukanlah jaminan bahwa mereka bisa mendapatkan iluminasi lebih dari Roh Kudus dibandingkan dengan jemaat-jemaat yang tidak memiliki gelar akademis di bidang Teologi. Bahkan yang seringkali terdengar adalah bahwa kotbah dari jemaat awam lebih hidup dan powerfull dibandingkan mereka yang belajar teologi. Hal ini tentu harus menjadi "PR" tersendiri bagi para sarjana Teologia, mengapa bisa demikian apa yang kurang atau salah?

Tuhan menganugerahkan Alkitab dengan tujuan supaya kehendakNya diketahui oleh umatnya; karena itu, penafsiran bukan monopoli sekelompok elite sarjana teologi (bdk. 1 Yoh 2:20, 27). Lagi pula janji Tuhan Yesus bahwa Roh Kudus akan memimpin ke dalam seluruh kebenaran (Yoh 16:13) adalah janji untuk setiap orang percaya. Itu berarti, setiap penyampai Firman yang mau sungguh-sungguh ingin memahami firman Tuhan, baik yang berlatar belakang pendidikan teologi maupun yang tidak, mempunyai hak istimewa 
untuk mendapat pimpinan Roh Kudus dalam mengerti Firman Tuhan dengan baik dan tepat. Pemahaman ini membawa implikasi:

(1) Bagi penyampai firman bergelar sarjana teologi untuk tetap rendah hati dalam menafsir Firman Tuhan. Setinggi apapun pendidikan teologinya, tanpa iluminasi Roh Kudus tidak mungkin ia dapar menegerti Alkitab dengan baik.

(2) Bagi penyampai firman yang tidak berkesempatan belajar Teologi secara formal, tidak perlu merasa kecil hati karena Roh Kudus tetap memberikan bimbingan-Nya. Namun untuk itu diperlukan tekad juga untuk terus mau belajar. Hanya yang patut dihindari atau harus berhati-hati dari penyampai firman yang tidak belajar teologi adalah mengkotbahkan hal-hal yang terkait dengan doktrin-doktrin.

d. Iluminasi Roh Kudus dalam menafsir teks membutuhkan kehidupan spritual yang sehat

W.H. Griffith Thomas berkata, "Di dalam pekerjaan Kristen, ada tiga elemen yang sangat penting, yaitu Roh Kusus sebagai sumber kuasa, Firman Tuhan sebagai berita, dan hamba Tuhan sebagai alat-Nya." ${ }^{, 25}$ Kehidupan spritual yang sehat adalah kehidupan rohani yang mampu menginstrospeksi diri, tidak merasa diri benar, tidak sombong, mudah diajar, rela mengampuni, dan hidup di dalam kasih dan ketaatan. Penyampai firman yang mempunyai kehidupan rohani yang demikian akan lebih sensitif kepada pimpina Roh Kudus dalam melihat arti yang benar dai suatu teks. Sebaliknya penyampau firman yang duniawi - tidak taat kepada kebenaran dan tidak memuliakan Tuhan dalam hidupnyasukar untuk mengerti firman Tuhan sepenuhnya (1 Kor. 3:1-3) dan "tidak memahami ajaran tentang kebenaran" (Ibrani 5:13), karena pikiran dan hatinya tidak selaras dengan kehendak Roh Kudus.

Iluminasi Roh Kudus dapat lebih mudah ditangkap oleh penyampai Firman yang memiliki kerohanian yang baik. Tidak mengherankan, penyampai Firman yang memiliki kehidupan spritual yang baik memahami hal-hal spritual lebih dalam sehingga Roh Kuduspun memakainya lebih efektif sebagai pemberita firman Tuhan. Hal tersebut selasaras dengan apa yang Paulus tulis dalam 2 Timotius 2:21, yang mengatakan bahwa, "Jika seorang menyucikan dirinya dari hal-hal yang jahat, ia akan menjadi perabot rumah untuk maksud yang mulia, ia dikuduskan, dipandang layak untuk dipakai tuannya dan disediakan untuk setiap pekerjaan yang mulia.”

${ }^{25}$ W.H. Griffith Thomas, Ministerial Life and Work (Grand Rapids, MI: Baker, 1974), 82. Dikutip dalam Roy B. Zuk, Spirit-Filled Teaching, 9. 
e. Iluminasi Roh Kudus dalam menafsir teks Alkitab tidak berarti pemberian wahyu yang baru

Iluminasi Roh Kudus memampukan kita untuk dapat memahami dengan tepat tentang segala sesuatumyang telah diajarkan di dalam Alkitab. Hal ini berarti Roh Kudus selalu bekerja dan sejalan dengan isi Alkitab, jadi tidak mengurangi, melampaui atau bahkan menambahkan. Setelah Alkitab dianugerahkan kepada kita, tidak ada sarana pewahyuan khusus lain yang dipakai Allah untuk berbicara kepada gereja-Nya selain melalui Alkitab dalam Perjanjian Lama dan Perjanjian Baru.

\section{Kemampuan berkotbah adalah Karunia Roh Kudus}

Kalau Benny Solihin menganalisa bahwa ada tiga alasan mengapa pengkotbah harus bergantung pada Roh Kudus, maka penulis menambahkan satu lagi. Pengkotbah harus bergantung kepada Roh Kudus adalah karena kemampuan berkotbah itu sendiri sesungguhnya adalah karunia atau pemberian dari Roh Kudus itu sendiri. Baiklah kita mulai dari pengertian karunia itu sendiri, dari definisi yang diberikan C. Peter Wagner dalam bukunya yang sudah diterjemahkan dalam bahasa Indonesia berjudul "Manfaat Karunia Roh": "Sebuah karunia Roh adalah perlengkapan istimewa yang diberikan oleh Roh Kudus kepada tiap-tiap anggota Tubuh Kristus menurut kasih karunia Allah untuk dipakai dalam konteks Tubuh itu." 26

Lebih lanjut Wagner berargumen bahwa kata Yunani yang biasa untuk karunia Roh adalah charisma, dari kata charis yang berarti kasih karunia. Jadi, ada hubungan yang sangat erat antara karunia-karunia Roh dan kasih karunia Allah. Dan yang penting dari frase terakhir dalam definisi itu ialah "untuk dipakai dalam konteks tubuh itu." Orangorang Kristen yang terlepas dari Tubuh Kristus tidak begitu berguna. Karunia-karunia Roh tidak direncanakan untuk orang-orang yang suka bekerja sendirian. Karunia Roh itu direncanakan untuk anggota-anggota Tubuh. ${ }^{27}$

Jack Mac Gorman dari Southwestern Baptist Seminary menegaskan, "Karuniakarunia ini bukan saja melakukan suatu fungsi, tetapi melakukannya di dalam jemaat. ${ }^{, 28}$ Wagner menyimpulkan, "Kebanyakan hal yang dilakukan Allah di dalam dunia dikerjakan melalui orang-orang Kristen yang bekerja bersama-sama di dalam masyarakat, saling

${ }^{26}$ C. Peter Wagner, Manfaat Karunia Roh untuk Pertumbuhan Gereja (Malang: Gandum Mas, t.th), 40 .

${ }^{27}$ Ibid., 41-42.

${ }^{28}$ Jack W. Mac Gorman, The Gifts of the Sprith (Nashville, Broadman Press, 1974), 31. Dikutip dalam Wagner, 42. 
melengkapi dengan karunia-karunia mereka di dalam jemaat-jemaat setempat mereka." ${ }^{29}$ Untuk semakin membuktikan bahwa kotbah adalah bagian dari karunia Roh, bisa di lihat dalam tiga daftar utama: ${ }^{30}$

Roma 12 menyebut karunia-karunia Roh yang berikut:

1. Nubuat (ucapan yang diilhami)

2. Pelayanan

3. Mengajar

4. Memberi nasehat (menggairahkan iman, mendorong)

5. Membagi-bagikan (menyumbang, kedermawanan, berbagi)

6. Kepemimpinan (kekuasaan, pemerintahan, kepengurusan)

7. Kemurahan (simpati, penghiburan kepada yang bersedih, menunjukkan kebaikan hati) I Korintus 12 menambahkan,

1. Berkata-kata dengan hikmat (nasihat yang bijaksana, tutur kata yang bijaksana)

2. Berkata-kata denan pengetahuan (belajar dengan pengetahuan)

3. Iman

4. Penyembuhan

5. Muljizat (melakukan perbuatan yang luar biasa)

6. Membedakan bermacam-macam roh (diskriminasi dalam perkara-perkara rohani)

7. Bahasa roh (berkata-kata dalam bahasa yang tidak pernah dipelajari, ucapan dalam bahasa ekstase)

8. Menafsirkan bahasa roh

9. Kerasulan

10. Pertolongan

11. Kepengurusan (pemerintahan, berusaha agar orang-orang lain bekerja-bersama-sama)

Efesus 4 menambahkan:

1. Pemberita Injil

2. Gembala (memelihara umat Allah)

Dari 20 daftar karunia Roh, hampir lebih dari setengahnya menunjukkan bahwa jelas sekali bahwa unsur-unsur tersebut diatas sangat terkait dengan diri si pengkotbah yang semakin menegaskan mengapa kotbah harus bergantung pada Roh Kudus, karena

\footnotetext{
${ }^{29}$ Wagner, Manfaat Karunia Roh, 42.

${ }^{30}$ Ibid., 59-60. Wagner disini tidak membicarakan hal kotbah, tetapi dari apa yang dipaparkan jelas sekali bahwa bagian-bagian kotbah adalah bagian besar dari karunia Roh.
} 
bagian-bagian yang terbesar dalam kotbah itu sendiri adalah hasil dari karunia-karunia Roh.

\section{Wujud Kebergantungan Penyampai Firman terhadap Roh Kudus}

Pemberita Firman Tuhan harus bergantung pada Roh Kudus dalam kehidupannya sehari-hari dengan menjaga hidup rohaninya. Dia adalah sosok yang menjaga kesalehan dan menyadari bahwa hidupnya adalah karena kasih karunia Allah yang dipanggil untuk menjadi pemberita Firman Allah. Untuk itu dia sadar bahwa di butuh urapan atau kuasa Allah dalam berkotbah dan untuk itu hidup kesehariannya adalah persiapan rohaninya. Jery Vines dan Jim Shaddix menggambarkan bahwa pemberita Firman Tuhan,

Sebagai salah seorang anak-Nya, pastikanlah Anda hidup saleh. Urapan Roh Kudus tidak dicadangkan untuk saat anda berdiri dan berkotbah. Namun lahir sewaktu anda berjalan hari demi hari bersama Allah dan bersama jemaat. Alkitab menyatakan "Sucikanlah dirimu, hai orang-orang yang mengangkat perkakas rumah Tuhan (Yesaya 52:11). Roh Allah yang kudus tidak akan mengurapi dan mengilhami jiwa yang tercemar dan tidak disucikan. Jangan biarkan seharipun berlalu tanpa pemeriksaan realita batin. ${ }^{31}$

Seorang pengkotbah sejati tidak hidup dalam kecemaran dosa, dan ia bukan hanya menjaga hidup benar sewaktu akan mempersiapkan dan akan menyampaikan Firmana Tuhan, tetapi ia harus memiliki keintiman bergaul dengan Roh Kudus hari-demi hari.

a. Doa setiap hari sebagai wujud ketergantungan pada Roh Kudus

Salah satu implikasi praktis dalam ketergantungan seorang pengkotbah dengan Roh Kudus adalah dinyatakan dalam kesehariannya di dalam berdoa secara pribadi. Tuhan Yesus dalam Injil Lukas di dalam hampir setiap pasalnya selalu mengisahkan Tuhan Yesus yang pergi ke empat sunyi, pagi-pagi benar untuk berdoa. Wujud bahwa pengkotbah mengabaikan kuasa Roh Kudus atau lebih mengutamakan akal atau logika mendapat peringatan dari buku "Berkotbah dengan Kuasa":

Pengkotbah juga bisa kehilangan Tuhan dalam pendalamannya. Karena begitu asikya menggeluti mekanika persiapan kotbah, ia melupakan kehadiran Tuhan dalam kehidupan pribadinya. Oleh sebab itu, ia perlu mengembangkan dan memupuk suatu praktik ibadah pribadi yang penuh semangat. ${ }^{32}$

\footnotetext{
${ }^{31}$ Vines dan Shaddix, Homiletika: Kuasa dalam Berkotbah, 96.

32 Ibid., 16.
} 
Nasehat yang sama diulang kembali dalam buku yang hampir satu abad terakhir menjadi buku pegangan bagi banyak seminary di Amerika Serikat,

Seorang ekspositor Firman, harus tahu bahwa ia tidak akan pernah mampu melayani sesama secara efektif apabila ia tidak melayani Allah... Penyampai Kotbah mereka di depan umum menunjukkan persekutuan pribadi pengkotbah dengan Tuhan. Ekspositor yang efektif tidak bisa meremehkan perlunya menumbuhkan perasaan tergantung pada Tuhan yang penuh rendah hati. Kita harus secara teratur menyerap kekuatan yang datang dari-Nya. Kekuatan itu datang sewaktu kita menanti di depan-Nya sambil berlutut dengan Alkitab terbuka. ${ }^{33}$

Urger dalam bukunya Expository Preaching juga mengingatkan hal yang kelihatan sederhana ini tetapi justru merupakan tiang utama dalam berkotbah,

Banyak ekspositor yang sebenarnya berbakat membutuhkan waktu lama untuk menemukan fakta sederhana ini. Sementara itu, ada pula yang tidak pernah menyadarinya. Akibatnya pelayanan mereka lebih bernuansa intelektual ketimbang rohaniah. Mereka menjelaskan kebenaran yang tertulis dalam Alkitab, namun tidak mereka gabungkan sebagaimana mestinya dengan Roh dan kekuatan Firman. ${ }^{34}$

E. M. Bounds dalam buku klasiknya tenteng "Power Through Prayer" menegaskan:

Berdoa, banyak berdoa, adalah harga pengurapan kotbah. Berdoa, banyak berdoa, adalah satu-satunya persyaratan untuk mempertahankan urapan ini. Tanpa doa yang tiada habis-habisnya, urapan Roh Kudus tidak akan pernah datang pada pengkotbah. Tanpa ketekunan berdoa, urapan tersebut seperti halnya mana yang terlalu lama disimpan, akan berulat. ${ }^{35}$

Jadi pengkotbah yang menyepelekan doa dan malah mengagungkan penggunaan prinsip-prinsip Hermeneutik dan penguasaan teori Homiletika, mestinya mau belajar dengan rendah hati. Sehingga tetap menempatkan doa sebagai ketergantungan dengan Roh Kudus tetapi juga tetap menggunakan prinsip-prinsip kotbah yang bertanggung jawab. Kendati demikian doa juga bukan merupakan "resep ajaib" yang menjamin efektivitas kotbah kita tanpa disiplin belajar juga harus dimengerti.

${ }^{33}$ Ibid, 85.

${ }^{34}$ Merrill Unger, Principles of Expository Preaching (Grand Rapids: Zondervan, 1985), 61. Dikutip oleh Jerry Vinnes dan Jim Shaddix, 17.

${ }^{35}$ E.M. Bounds, Power Through Prayer (Grand Rapids, MI: Baker, 1991), 76. Dikutip dalam Jim Shaddix, 98. 
b. Membaca Alkitab setiap hari sebagai wujud ketergantungan pada Roh Kudus

Doa dan membaca Alkitab adalah dua sisi dari mata uang logam yang tidak boleh ditinggalkan oleh seorang pengkotbah di dalam kesehariannya, sesibuk apapun dia. Kerinduan membaca Alkitab bagi seorang pengkotbah akan muncul sesungguhnya dimulai dari keyakinan bahwa Firman Tuhan merupakan bagian terpenting dalam acara menyampaikan kotbah. Untuk bisa seperti itu seorang pengkotbah dituntut harus memiliki kepercayaan bahwa Alkitab adalah Firman Allah, dan bukan hanya percaya bahwa sebagian Alkitab adalah Firman Allah. Dasar keyakinan inilah yang akan membuat seorang pengkotbah sejati mencintai Firman Tuhan sehingga akan dengan penuh ketekunan membaca terus sampai berulang-ulang dan baru bisa dengan penuh keyakinan akan dapat menyampaikan Firman Tuhan dengan mantap karena telah mendalami dan menguasai isi dari Firman Tuhan secara keseluruhan. Tentang hal ini Urger telah memberi peringatan:

Mereka yang menganggap pandangan pengkotbah terhadap Alkitab tidaklah penting dan bukan faktor yang menentukan efektif tidaknya kotbahnya. Anggapan semacam ini ikut bertanggung jawab atas turunnya mutu penyampaian kotbah alkitabiah selama abad kedua puluh. Sebaliknya, semua keyakinan Anda mengenai Alkitab langsung mempengaruhi motivasi dan hasil penyampaian kotbah Anda. ${ }^{36}$

Unger juga mengugkapkan keprihatinannya atas hal ini dengan berkata:

Apabila Alkitab hanya dianggap sebagai kitab yang memuat Firman Tuhan, bukannya benar-benar merupakan Firman Tuhan, tentu saja perasaan wajib mempelajari teksnya dengan seksama akan menurun, ataupun sistematika teologinya, atau menyampaikan pesannya dengan penuh wibawa. ${ }^{37}$

Betapa pentingnya seorang pengkotbah memiliki keteraturan dalam mendalami alkitab dan berdoa sangat menjadi catatan penting seorang pengkotbah kembali dinasehatkan:

Bersekutulah secara teratur dengan Allah, Apabila Anda menghendaki Roh Kudus menghampiri Anda dengan kuasa-Nya yang besar dalam penyampaian kotbah, Anda harus memelihara persekutuan dengannya melalui pendalaman Alkitab dan berdoa secara teratur. Tak seorangpun bisa dipakai secara efektif tanpa setiap hari bersekutu dengan Tuhan. ${ }^{38}$

\footnotetext{
${ }^{36}$ Jim Shaddix., 66.

${ }^{37}$ Unger, 18, dikutip dalam Vines dan Shaddix, Homiletika: Kuasa dalam Berkotbah, 67.

38 Ibid., 96.
} 
Jadi kehidupan pribadi pengkotbah yang menjaga kualitas hidup rohani hari demi hari dan diwujudkan dalam hubungannya yang intim dalam doa serta saat teduhnya dalam membaca dan merenungkan Firman Tuhan, ditambah dia mau bekerja keras dalam menggunakan prinsip Hermeneutik serta kaidah dalam berhomiletika akan dapat menghadirkan kotbah-kotbah yang berkualitas. Karena disana ada unsur pengkotbah yang mengandalkan kuasa Roh Kudus dan yang mau belajar dengan giat.

\section{Kesimpulan}

Ada ungkapan, "tanpa ada pertobatan diatas mimbar, tidak ada pertobatan di bangku jemaat”. Kalau ini benar, maka para pengkotbah ditutut untuk bertobat terlebih dahulu dengan menjadi sosok pengkotbah yang harus dengan sikap rendah hati mau menjadi penyampai Firman yang bergantung pada Roh Kudus. Untuk itu dia harus tahu alasananya mengapa dia harus bergantung pada Roh Kudus? Yaitu dengan menyadari penuh bahwa kotbah bukanlah penemuan manusia, tetapi kreasi Tuhan; hanya Kuasa Roh Kudus yang dapat mengubah manusia; Alkitab sebagai dasar kotbah diinspirasi dan diiluminasikan oleh Roh Kudus; kemampuan berkotbah adalah Karunia Roh Kudus.

Selanjutnya, dia menjaga kesalehan hidup dalam keseharian lewat ibadah pribadi dengan doa dan ketekunan membaca serta merenungakan Firman Tuhan, dan tentu semuanya itu dilakukan tanpa mengorbankan untuk sebuah persiapan yang mendalam dari proses studi yang penuh tanggungjawab dalam menafsir Alkitab. Maka dari sosok pengkotbah yang demikian akan dipenuhi oleh kuasa Roh Kudus dalam setiap penyampaaianya kotbahnya, sehingga akan ada perubahan-perubahan hidup dari jemaatjemaat yang mendengarkan karena yang Roh Kudus turut bekerja menjamah untuk dibawa kepada keinsafan akan dosa, kebenaran dan penghakiman (Yohanes 16:8-11).

\section{Kepustakaan}

Azurdian III, Aruro G. Sprit Empowered Preaching. Yogyakarta: Andi, 2009.

Bounds, E.M. Power Through Prayer. Grand Rapids Baker, 1991.

Calvin, John. Intitutio. Jakarta: Gunung Mulia, 1993.

Graham, Billy. Roh Kudus: Kuasa Allah dalam Hidup Anda. Bandung: Lembaga Literatur Babtis, 1985.

Horton, Stanley M. Oknum Roh Kudus. Malang: Gandum Mas, T.th.

Lukas, Daniel. Pengantar Theologia Kristen I. Bandung: Kalam Hidup, 1992. 
Mac Arthur Jr., John. Rediscovering Expository preaching: Balancing the Science and Art of Biblical Expository, ed. Richard L. Mayhue; Dalas: Word, 1992.

Mac Gorman, Jack W. The Gifts of the Sprith. Nashville: Broadman Press, 1974.

Shipman, Michael K. Pembaharuan Pelayanan Mimbar. Bandung: Yayasan Kalam Hidup, 2006.

Solihin, Benny. 7 Langkah menyusun Khotbah yang Mengubah Kehidupan. Malang: Literatur SAAT, 2014.

Sudjono, Andreas, "Inspirasi Roh Kudus bagi Pendeta dalam mempersiapkan

Khotbahnya," sumber dari:

sttintheos.ac.id/ejournal/index.php/antusias/article/download/70/69, dibuka pada 2802-2018.

Thomas, W.H. Griffith. Ministerial Life and Work. Grand Rapids: Baker 1974.

Unger, Merrill. Principles of Expository Preaching. Grand Rapids: Zondervan, 1985.

Wagner, C. Peter. Manfaat Karunia Roh untuk Pertumbuhan Gereja. Malang: Gandum Mas, t.th.

Vines, Jerry dan Jim Shaddix. Homiletika: Kuasa dalam Berkhotbah: Persiapan dan Penyampaian Khotbah. Malang: Gandum Mas, 2002. 